\title{
Comparative analysis of energy security in the Nordic countries: The role of renewable energy resources in diversification
}

Cite as: J. Renewable Sustainable Energy 4, 062701 (2012); https://doi.org/10.1063/1.4765695

Submitted: 01 July 2012 . Accepted: 12 October 2012 . Published Online: 12 November 2012

Alireza Aslani, Erkki Antila, and Kau-Fui V. Wong

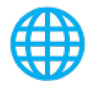

\section{ARTICLES YOU MAY BE INTERESTED IN}

Evaluation of renewable energy development in power generation in Finland

Journal of Renewable and Sustainable Energy 5, 063132 (2013); https://

doi.org/10.1063/1.4855095

Strategic variables of commercialization of renewable energy technologies

Journal of Renewable and Sustainable Energy 7, 023105 (2015); https: //

doi.org/10.1063/1.4914078

Integrated energy and environmental systems analysis methodology for achieving low carbon cities

Journal of Renewable and Sustainable Energy 2, 031012 (2010); https://

doi.org/10.1063/1.3456367

\section{AIP Author Services English Language Editing}




\title{
Comparative analysis of energy security in the Nordic countries: The role of renewable energy resources in diversification
}

\author{
Alireza Aslani, ${ }^{1, a)}$ Erkki Antila, $^{2}$ and Kau-Fui V. Wong ${ }^{3}$ \\ ${ }^{1}$ Production Department, Faculty of Technology, University of Vaasa, Vaasa 65101, \\ Finland, and Department of Engineering and Public Policy, Carnegie Mellon University, \\ 5000 Forbes Ave., Pittsburgh, Pennsylvania 15213, USA \\ ${ }^{2}$ Department of Electrical Engineering and Energy Technology, Faculty of Technology, \\ University of Vaasa, Vaasa 65101, Finland \\ ${ }^{3}$ Department of Mechanical and Aerospace Engineering, College of Engineering, \\ University of Miami, Miami, Florida 33146, USA
}

(Received 1 July 2012; accepted 12 October 2012; published online 12 November 2012)

\begin{abstract}
Security of energy supply has been one of the important debates among citizens and governments of the Nordic countries after the first energy crisis. In response, diversification was defined as the heart strategy to reach a certain level of energy supply. This article discusses about the level of energy security in the Nordic countries with comparison to other developed countries and their neighbors. Then, the support schemes and policies to achieve the energy security and diversification are reviewed based on the system thinking approach with especial focus on the renewable energy resources. This approach provides a unique and powerful tool to explain the complexity and the relationships among the elements of the support schemes in the energy security analysis. (C) 2012 American Institute of Physics.
\end{abstract}

[http://dx.doi.org/10.1063/1.4765695]

\section{INTRODUCTION}

Increasing world demand for energy, fluctuating carbon based fuel prices, uncertain oil and gas supplies arising from geopolitical concerns, and global warming are the challenges that the Nordic citizens and governments (Finland, Sweden, Norway, Denmark, and Iceland) realized to have the secure and safe supply of energy. From the economic recession in 1970s and early 1980s, most energy importers have developed various strategies to enhance energy security such as upstream investment in producing countries, utilizing domestic and local natural resources, long-term contracting at premium prices, diversifying fuels and suppliers, developing dual fuel technologies, decentralized forms of utilization, efficiency and conservation, building strategic reserves, etc. ${ }^{1,14}$ However today, more than in the past, environmental considerations impact on energy security calculations. Therefore, policies like development of renewable alternatives and non-carbon generation technologies have been encouraged to contribute diversification and security of energy supply. Furthermore, local availability of alternative resources is also one of the main drivers for governments to attend diversification in their energy security strategies.

The studies show that the Nordic countries including Finland, Sweden, Norway, Denmark, and Iceland are good examples of this utilization. They have made considerable and successful efforts in the utilization of renewable energy resources (RER). For instance, while this region had only $0.37 \%$ (less than $1 \%$ ) of the world's population and $1.35 \%$ of GDP share (PPP) in the world in 2011 (Table I), the average utilization of RER for electricity generation was $62.82 \%$ (Table II). In 2010, Norway and Iceland are among top 10 renewable electricity producers with $96.6 \%$ and $100 \%$ of their electricity generation from RER in the world. ${ }^{12}$

\footnotetext{
${ }^{\text {a) }}$ Author to whom correspondence should be addressed. Electronic mail: alasl@uwasa.fi. Tel.: +35844255 0010. Visiting scholar at Carnegie Mellon University.
} 
TABLE I. Basic statistics overview of the Nordic countries. ${ }^{2-9}$

\begin{tabular}{lrrcc}
\hline \hline & Area $\left(\mathrm{m}^{2}\right)^{\mathrm{a}}$ & Population $^{\mathrm{b}}$ & GDP (PPP) (\$million) & GDP (PPP) per capita $(\$)^{\mathrm{d}}$ \\
\hline World & 148940000 & 7022000000 & 78897426 & \\
Finland & 303815 & 5411500 & 195723 & 36236 \\
Sweden & 410335 & 9495113 & 381719 & 40394 \\
Norway & 304282 & 5019200 & 265911 & 53471 \\
Denmark & 42434 & 5584758 & 206586 & 37152 \\
Iceland & 100250 & 320060 & 12409 & 38061 \\
Nordic & 1161116 & 25830631 & 1062348 & 11489 \\
Nordic's share compare & 0.78 & 0.37 & 1.35 & $\ldots$ \\
to the world (\%) & & & & \\
\hline \hline
\end{tabular}

${ }^{\mathrm{a}}$ United Nations statistics.

${ }^{\mathrm{b}}$ Official websites of the government-April 2012.

'International Monetary Fund-2011.

${ }^{\mathrm{d}}$ International Monetary Fund-2011.

Table III and Figure 1 compare the situation of the Nordic countries among top 33 richest countries (T33) in terms of share of RER as one of the important diversification strategies in electricity generation in 2009. While the share of RER in the electricity generation in the T33 is $23.58 \%$, it is $62.82 \%$ for the Nordic countries (2.66 times more than the T33 (A/B)). Indeed, the T33 produce $23.58 \%$ of their electricity from RER (B), while the share of the Nordic countries in this generation is $43 \%(\mathrm{~B} / \mathrm{C})$. As some of these 33 rich countries like Qatar, Kuwait, United Arab Emirates, Singapore, and Oman do not use RER in the economic level, the share of the Nordic countries in the electricity generation from RER is about $31 \%$ without those five countries $(\mathrm{D} / \mathrm{E})$.

Therefore, while the Nordic countries are among successful countries in the diffusion of RER, a few researchers have discussed about drivers of energy diversification in this region as a package including all the five countries. Therefore, the study of this region in terms of diversification policies and RE promotion and thereby energy security is one of the best case studies to be followed by other countries and regions. For instance, Finland and Sweden are two of the leading bioenergy-using countries in the world. Norway also with hydro power development, Denmark with high growth in wind power utilization, and Iceland with geothermal are the successful examples of the utilization of RER. On the other hand, since the Nordic countries have their own specific and distinguished approaches in political, economic, and social welfare (Nordic model), the study of energy security in this region, as one of the main drivers of sustainable development, is beneficial and noticeable. As an example, while Iceland was one of the Europe's poorest countries during the 20th century with dependence upon peat and imported coal for its energy, it has developed to a country with a high standard of living in which roughly $86.3 \%$ of primary energy is derived from indigenous RER.

The aim of this research is to provide an overview to study the role of diversification and RE in the national energy security objectives of the Nordic countries. The research discusses about the level of energy security in the Nordic countries with comparison to other developed

TABLE II. Share of RER in the total electricity generation (\%) in the Nordic in $2009 .{ }^{10,11}$

\begin{tabular}{lc}
\hline \hline & Total electricity generation from RER (\%) \\
\hline Finland & 31.56 \\
Sweden & 58.52 \\
Norway & 96.63 \\
Denmark & 27.4 \\
Iceland & 100 \\
Average & 62.82 \\
\hline \hline
\end{tabular}


TABLE III. Average share of RER in the electricity generation among the Nordic and top 33 richest countries based on GDP (PPP) per capita. ${ }^{10,12}$

\begin{tabular}{cc}
\hline \hline & $\begin{array}{c}\text { Share of RER in electricity } \\
\text { generation-average (2009) (\%) }\end{array}$ \\
\hline $\mathrm{A}^{\mathrm{a}}$ & 62.82 \\
$\mathrm{~B}^{\mathrm{b}}$ & 23.58 \\
$\mathrm{C}^{\mathrm{c}}$ & 16.51 \\
$\mathrm{D}^{\mathrm{d}}$ & 30 \\
$\mathrm{E}^{\mathrm{e}}$ & 23 \\
\hline \hline
\end{tabular}

${ }^{a}$ Nordic countries.

${ }^{\mathrm{b}}$ Top 33 richest countries based on GDP (PPP) per capita.

${ }^{c} B$ without Nordic countries.

${ }^{\mathrm{d}} \mathrm{B}$ without countries which do not utilize RER for electricity generation such as Qatar, Kuwait, and United Arab Emirates.

${ }^{\mathrm{e}} \mathrm{D}$ without Nordic countries.

countries and their neighbors. Then, it points out drivers that have been most effective in the diffusion of RE in this region from energy security viewpoint. To achieve a better understanding of the high level of energy security, different support schemes and strategies are reviewed based on system thinking theory by using feedback structure loop.

\section{OVERVIEW OF ENERGY SECURITY INDICATORS IN THE NORDIC COUNTRIES}

Generally, the Nordic countries are energy intensive countries because of cold climate, the wide sparsely populated areas with long distances (especially Finland, Sweden, and Norway), the high standard of living, and energy intensive industry. For instance, Finland's per capita energy consumption is the highest in Europe.

\section{A. Energy consumption, imports, and exports in the Nordic countries}

Figure 2 illustrates the primary energy consumption in the Nordic countries in 2009.

The share of oil in energy supply has been substantially reduced in the last three decades in the Nordic countries, especially in Finland and Sweden. For example, Finland dropped the share of oil products from $64 \%$ in 1973 to $28.7 \%$ in 2009 . This reduction is important because at the same time the Finland's population increased $18 \%$ as the penetration factor of personal automobile has been multiplied too. Meanwhile, the use of oil and oil products dropped off over 43\% in Sweden since 1970.

The energy consumption mix for electricity plants, combined heat and power plants (CHP), and heat plants is depicted in Fig. 3. Due to the geographic situation of the Nordic countries,

\section{Share of RER in Electricity Generation- average(2009)}

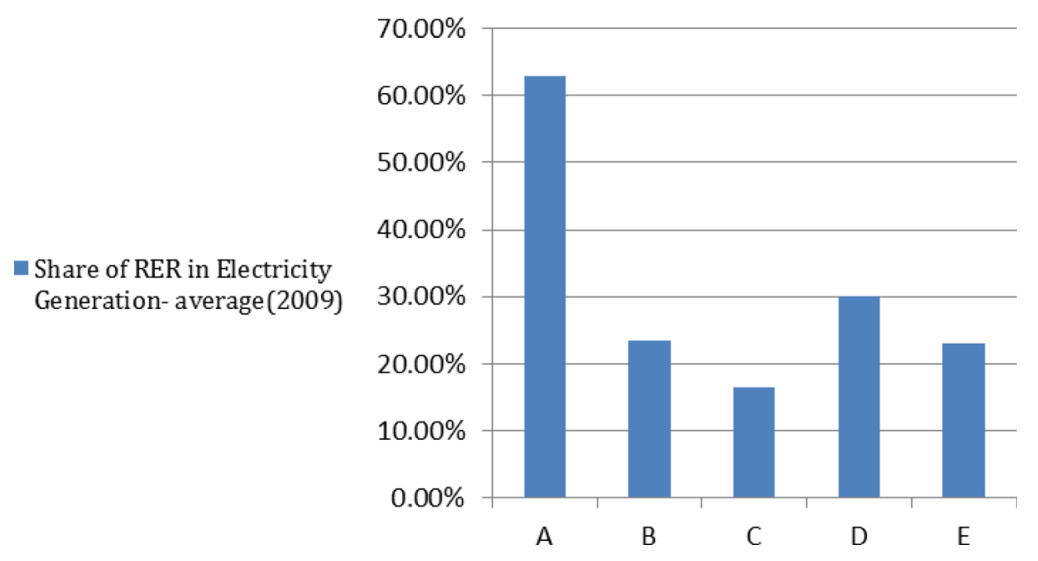

FIG. 1. Average share of RER in electricity generation among the Nordic and top 33 rich countries. 


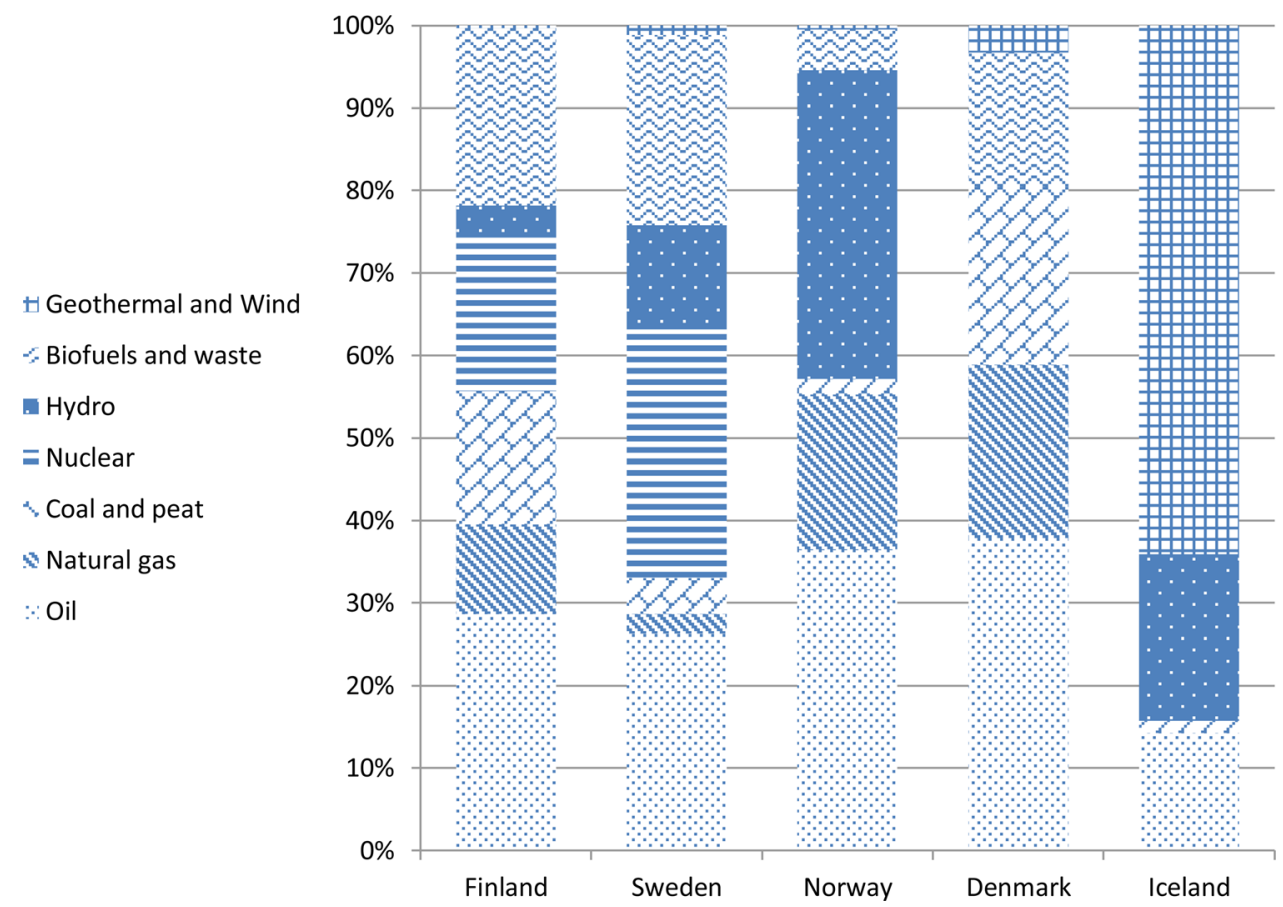

FIG. 2. Primary energy consumption in the Nordic Countries (Mtoe: million tons of oil equivalent), 2009. ${ }^{10}$

the solar energy is not in the priority of their economic utilization. As an example, the country's geological characteristics have endowed Iceland with an abundant supply of geothermal resources and hydro power. This country derived $84.3 \%$ of its primary energy from indigenous RER (64.1\% geothermal and 20.2\% hydropower) (Figs. 2 and 3). It is noteworthy that current and dominate utilization of geothermal energy in Iceland is for heating (Fig. 3).

The national target for Finland is to increase the electricity production from biomass with major part derives from the forest industry. ${ }^{21}$ Pellets market also is one of the rapidly developed

Biofuels and Waste

+ Geothermal, Solar and Wind

- Hydro

$=$ Nuclear

Natural Gas

Oil Products

$<$ Coal and Peat

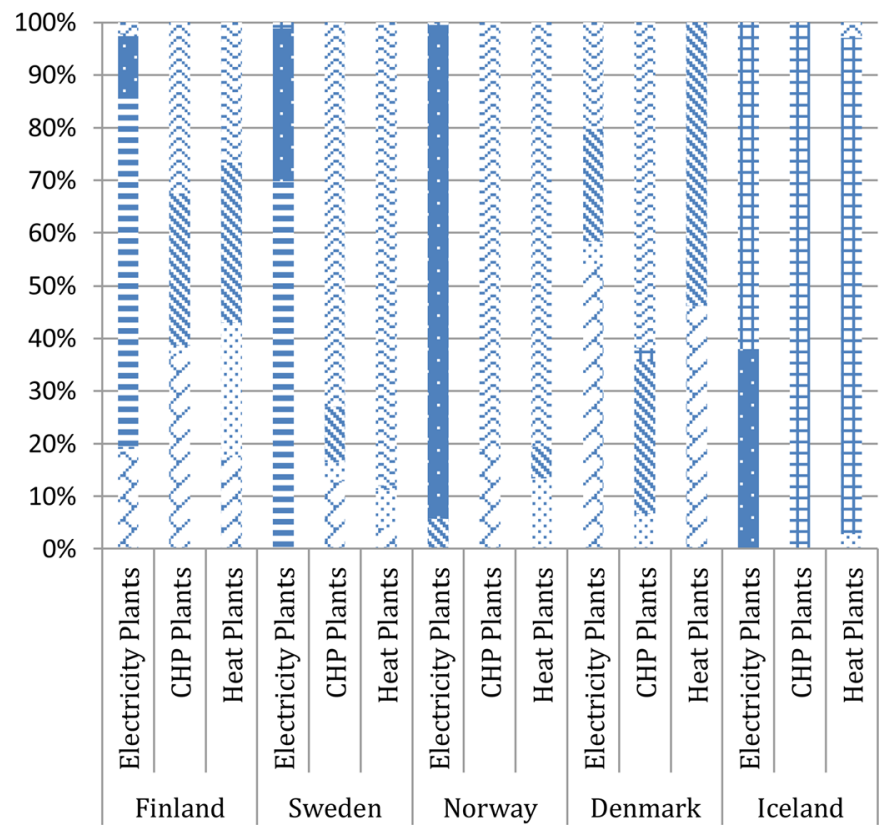

FIG. 3. Energy consumption mix for electricity and heat plants (2009). ${ }^{10}$ 
TABLE IV. Total primary energy supply-fossil fuels, imports, and exports (TPES) (ktoe), 2009. ${ }^{10}$

\begin{tabular}{llrrrr}
\hline \hline \multicolumn{1}{c}{ Total primary energy supply (ktoe) } & Coal and peat & Crude oil & Oil product & Natural gas \\
\hline Finland & Imports & 3803 & 11764 & 5076 & 3483 \\
& Exports & -13 & -117 & -6622 & 0 \\
\multirow{3}{*}{ Sweden } & Imports & 1541 & 19594 & 7369 & 1101 \\
& Exports & -188 & -378 & -11684 & 0 \\
\multirow{2}{*}{ Norway } & Imports & 474 & 1000 & 4757 & 0 \\
& Exports & -1609 & -88144 & -16163 & -85170 \\
\multirow{3}{*}{ Denmark } & Imports & 3967 & 3611 & 5365 & 0 \\
& Exports & -38 & -9081 & -4504 & -3578 \\
\multirow{3}{*}{ Iceland } & Imports & 80 & 0 & 926 & 0 \\
& Exports & 0 & 0 & -50 & 0 \\
\hline \hline
\end{tabular}

industries in Sweden in recent years and makes Sweden as one of the world's leading producers and users of pellets in the energy supply. On the other hand, Denmark has a leading role in the field of wind power. The expansion of wind power has been an important goal in the Danish energy policy and supply.

Table IV shows the amount of fossil fuels imports and exports in the Nordic region. For example, Finland imported about 38303 Ktoe Coal and peat from Russia, Poland, and North America. Sweden also imported about 1101 ktoe from Denmark in 2009.

As Fig. 4 illustrates, Denmark and Norway export crude oil and natural gas. In 1970s, energy supply was largely based on oil in Denmark (89\% of TPES) which was severely affected by oil crisis. To reduce the oil demand and TPES as a whole, the Danish government introduced energy efficiency measures and developed combined heat and power production and RE. ${ }^{11}$

\section{B. Energy security indicators for Nordic countries}

The data analysis of energy consumption, imports, and exports highlights the important role of energy security and its subsets such as diversification of energy sources and import dependency on policy and decision makers. Several researches have been developed to measure and implement the level of energy security in different countries. A joint work by the United

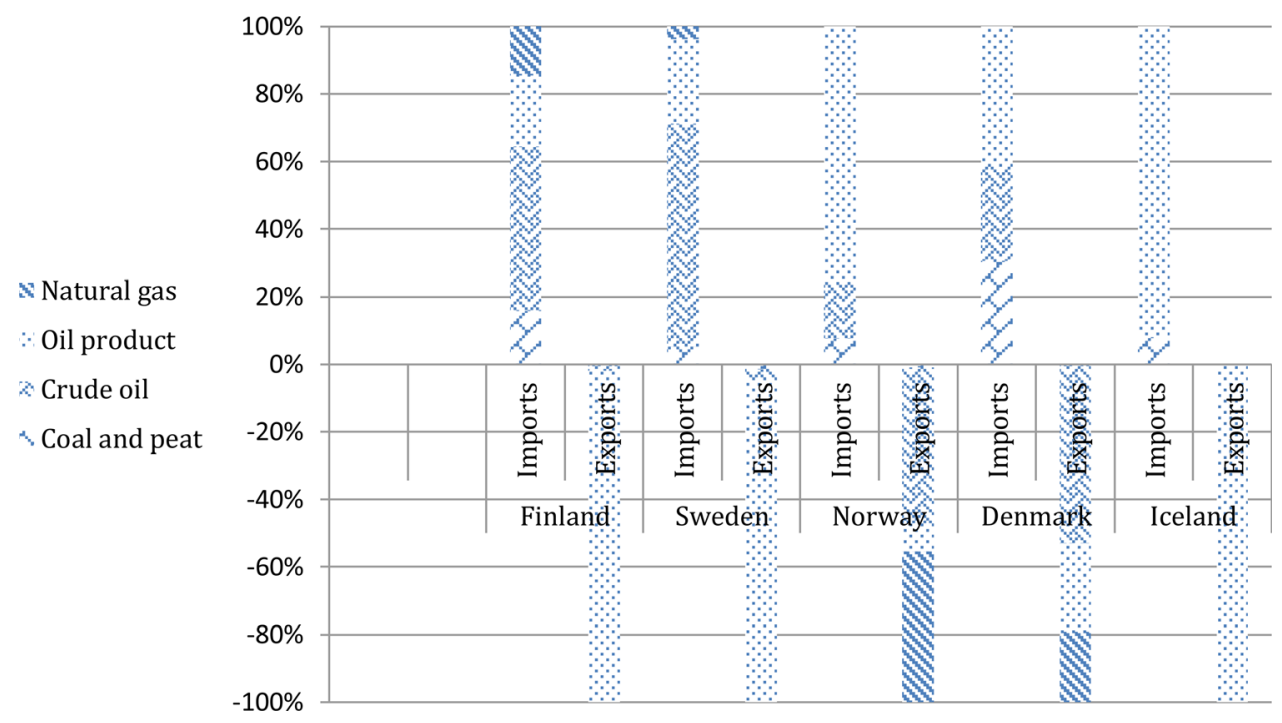

FIG. 4. Share of fossil resources in Nordic countries (imports +, exports -), 2009. ${ }^{10}$ 
Nations Department of Economic and Social Affairs, International Energy Agency (IEA), International Atomic Energy Agency, Eurostat and European Environment Agency has identified 4 social, 16 economic, and 10 environmental indicators for energy security. ${ }^{13-18}$ Recently, a set of indicators has been introduced to evaluate the energy security from the diversity of energy supply viewpoint. ${ }^{14}$ The basic idea for diversification indicators was borrowed from portfolio theory in finance. According to this theory, the overall risk of energy supply is smaller if there is a diversified portfolio of suppliers. ${ }^{19}$ Diversification in supply sources can reduce vulnerability of supply disruptions from a particular source. Furthermore, diversification decreases the market power of any one supplier and the risks of higher prices. ${ }^{20}$ Following two main and valid indicators are implemented for the Nordic countries and six selected countries. The countries were selected based on three factors of GDP similarity with the Nordic countries, close political and economic relations with the Nordic countries, and leading in the diversification strategy in their countries.

\section{Diversification of energy supply sources (DESS)}

This indicator considers both the significance of diversification in terms of abundance and equitability of sources. ${ }^{22}$

$$
\operatorname{DESS}=-\left(\frac{\sum_{\mathrm{i}=1}^{\mathrm{n}} \mathrm{ai} * \operatorname{Ln}(\mathrm{ai})}{\operatorname{Ln}(\mathrm{n})}\right) .
$$

In this equation ai is the share of each primary energy sources in total energy supply (or, other defined supply factor). $\mathrm{n}$ is also the number of sources based on IEA categorization (coal and peat, oil, natural gas, nuclear, hydro, geothermal and solar and wind, and biofuel and waste). In this research the DESS has been calculated from IEA data for 2009 in two different levels: total energy supply (Fig. 5), and total energy supply of electricity and heat plants generation (Fig. 6). Generally, higher DESS score for a country means high energy security and low risk.

To calculate the DESS index, the overall consumption including different sectors such as transport was used. According to Figure 5, Finland and Sweden have the top diversified energy portfolios among other countries with the scores of 0.86 and 0.82 . As they are two countries without significant domestic resources, the level of diversification in those countries is noteworthy. The average score of the eleven selected countries is 0.71 in which Canada and Germany have the scores of 0.81 and 0.80 . The scores of Denmark, Norway and Iceland are 0.74, 0.66, and 0.49. So, Finland, Sweden, and Denmark have the scores more than the average scores among the Nordic countries. However, the low scores of Norway and Iceland are not necessarily a handicap. It can be debated from the second indicator viewpoint (NID) and the level of their dependency on their domestic resources in the electricity generation (Fig. 3).

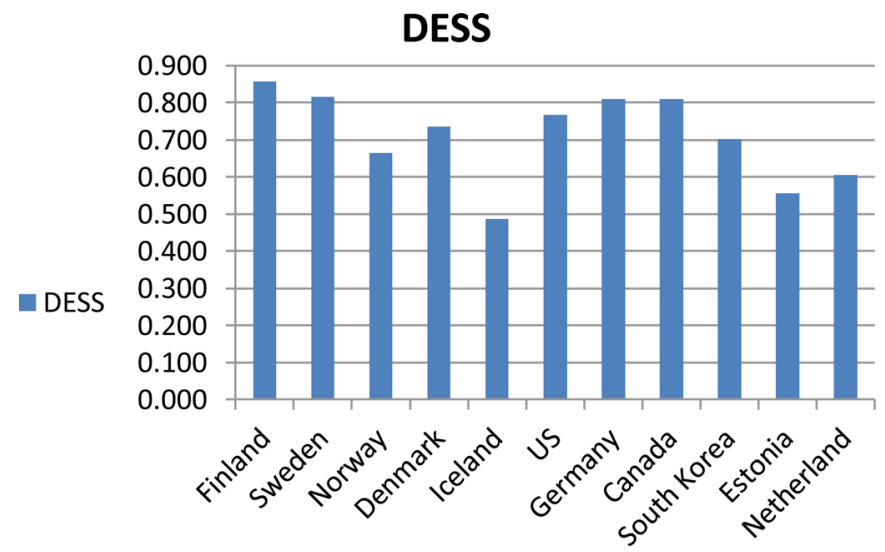

FIG. 5. DESS in the level of total energy supply (2009). 


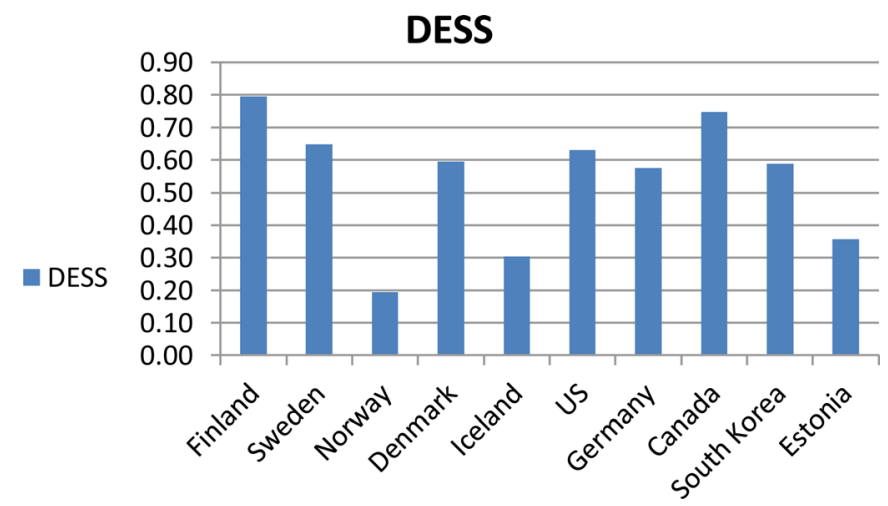

FIG. 6. DESS in the level of total energy supply for electricity and heat plants generation.

Next, the DESS index was calculated based on the consumption of electricity and heat sector (Fig. 6). Due to the geographical situation of the Nordic countries (located in the cold belt), this index directly effect on the political decisions related to energy security.

Figure 6 along with Figure 3 can analyze and compare the scores of each Nordic country in the security of energy supply in their electricity sectors. For example, while the overall DESS index for Norway is $36.6 \%$ more than Iceland (Fig. 5), the DESS for electricity and heat plants sectors is $64 \%$ of Iceland (Fig. 6). This is because of high dependency in Norway to hydropower resources and high weight of electricity plants compared with CHP plants and heat plants (Fig. 3).

\section{Net import dependency}

NID reflects the impact of both diversification and imports on energy supply security. ${ }^{23}$

$$
\mathrm{NID}=1-\frac{\frac{\sum_{\mathrm{i}=1}^{\mathrm{n}}((1-\mathrm{mi}) * \mathrm{a} * \operatorname{Ln}(\mathrm{ai}))}{\operatorname{Ln}(\mathrm{n})}}{\operatorname{DESS}},
$$

mi is the import share for energy source i. Obviously, less NID score for a country means lower level of dependency on imported resources, higher energy security, and lower risk (Fig. 7).

Based on the Figure 7, The NID average of the Nordic countries is 0.33. Since Norway is one of the exporters of crude oil and natural gas, the NID index for the Nordic countries without Norway is 0.394 (39.4\%) which is less than average of selected countries: $0.463(0.467$ without Norway). This means that although the Nordic countries (without Norway and in some

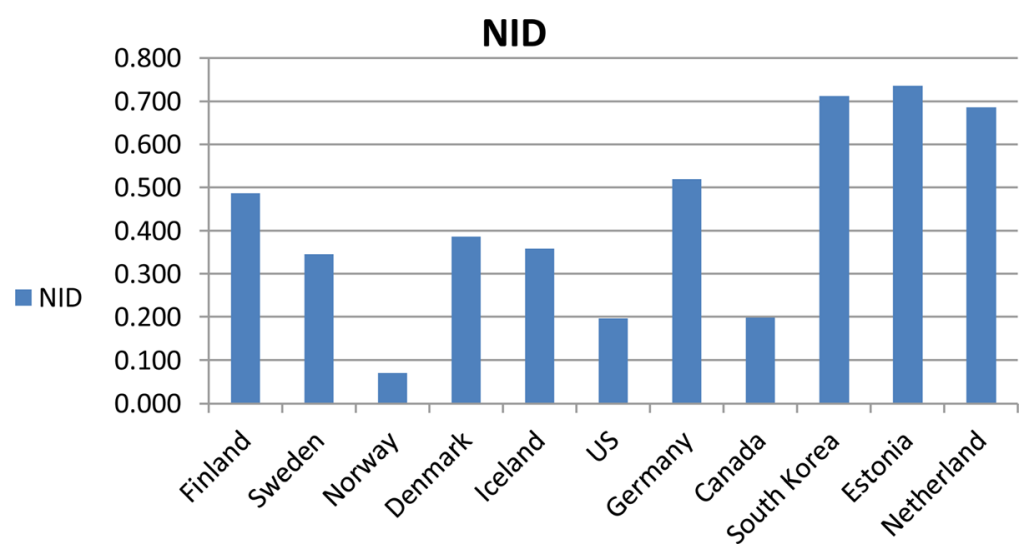

FIG. 7. Net import dependency. 
cases Denmark) have a high level of dependency on fossil fuels, they could implement other resources such as renewable and nuclear (just for Finland and Sweden) in their energy policies to manage a healthy economy.

\section{STRATEGIES FOR ENHANCING ENERGY SECURITY IN THE NORDIC COUNTRIES}

Discussed indicators and the literature of this article show that the Nordic countries have a high level of energy security in comparison with other developed countries and their neighbors. In particular, countries like Finland and Sweden with little domestic resources are able to sustain a reasonable economic growth, a high level of social welfare, and a high GDP. The investigations and observations of the authors indicate that a set of strategies and policies have provided the circumstances of these successes. Most common schemes and strategies are the following:

(1) Investment supports (in the levels of government and private sector).

(2) Developing storage capacity for fuels (e.g., strategic reserves).

(3) Diffusion of renewable energy alternatives. ${ }^{24}$

(4) R\&D supports.

(5) Increasing energy efficiency and conservation.

(6) Tax incentives including tax rebates, direct production support, environmental bonus, etc.

(7) Taxation of fossil fuels in heat production.

(8) Engaging in long-term supply agreements with suppliers.

(9) Feed-in-tariffs (fixed price or premium). ${ }^{29}$

Table V shows a short description of each policy and scheme.

Figure 8 illustrates the inter-relations of the influencing factors (Table V) in the frame of system thinking loops. Among a number of variables within the sub-systems of energy security, only main variables were included in this model. The main advantage of this kind of analysis is to understand the feedback structure of each scheme and policy related to the energy security. ${ }^{25,26}$ Therefore, using

TABLE V. Short description or example of policies and support schemes.

\begin{tabular}{|c|c|}
\hline Support scheme & Description \\
\hline Investment supports & $\begin{array}{l}\text { Including governmental investments, investment aids for private sector } \\
\text { participation, Tax reduction for private investment on especial source } \\
\text { (e.g., tax reduction for Biomass development in Sweden and Finland) }\end{array}$ \\
\hline Developing storage capacity & $\begin{array}{l}\text { In order to decrease the fluctuation of fossil fuels prices and emergency } \\
\text { conditions in different locations, etc. }\end{array}$ \\
\hline $\begin{array}{l}\text { Diffusion of renewable energy } \\
\text { alternatives in advanced levels }\end{array}$ & $\begin{array}{l}\text { Via direct and indirect investment and R\&D supports, tax refund, } \\
\text { funding, etc.E.g., a project is developing to improve the smart energy } \\
\text { systems in the Ostrobothnia region (Finland) }\end{array}$ \\
\hline R\&D supports & $\begin{array}{l}\text { Funds for technology development and commercialization of RE } \\
\text { technologies, energy efficiency and conservation, and energy use of waste, } \\
\text { green certificates (for example, Tekes, Fortum, and VTT in Finland, ERP } \\
\text { and DPRE in Denmark, Norwegian Research Council, Gassnova, } \\
\text { and Innovation Norway in Norway, etc.) }\end{array}$ \\
\hline $\begin{array}{l}\text { Increasing energy efficiency } \\
\text { and conservation }\end{array}$ & $\begin{array}{l}\text { E.g., encouragement of fuel efficiency, mandatory technical examination } \\
\text { of vehicles }\end{array}$ \\
\hline Tax incentives & E.g., tax refund for electricity produced from RE \\
\hline Taxation of fossil fuels & $\begin{array}{l}\text { Tax paid (basic and surtax) for fossil fuels used for heat production improves } \\
\text { the price competitiveness of bioenergy. Also, since electricity from } \\
\text { bio energy is mainly produced in CHP power plants, fossil fuel taxation } \\
\text { indirectly enhances electricity production from RER }\end{array}$ \\
\hline Long-term supply agreements & $\begin{array}{l}\text { E.g., Nordel contracts among the Nordic countries, EKO-energy } \\
\text { agreement in Sweden, Finland, and Russia energy contracts, etc. }\end{array}$ \\
\hline Feed-in-tariffs & $\begin{array}{l}\text { I.e., an obligation for retailers of electricity to buy whatever quantity } \\
\text { of green electricity is supplied at a price determined by the regulator }\end{array}$ \\
\hline
\end{tabular}




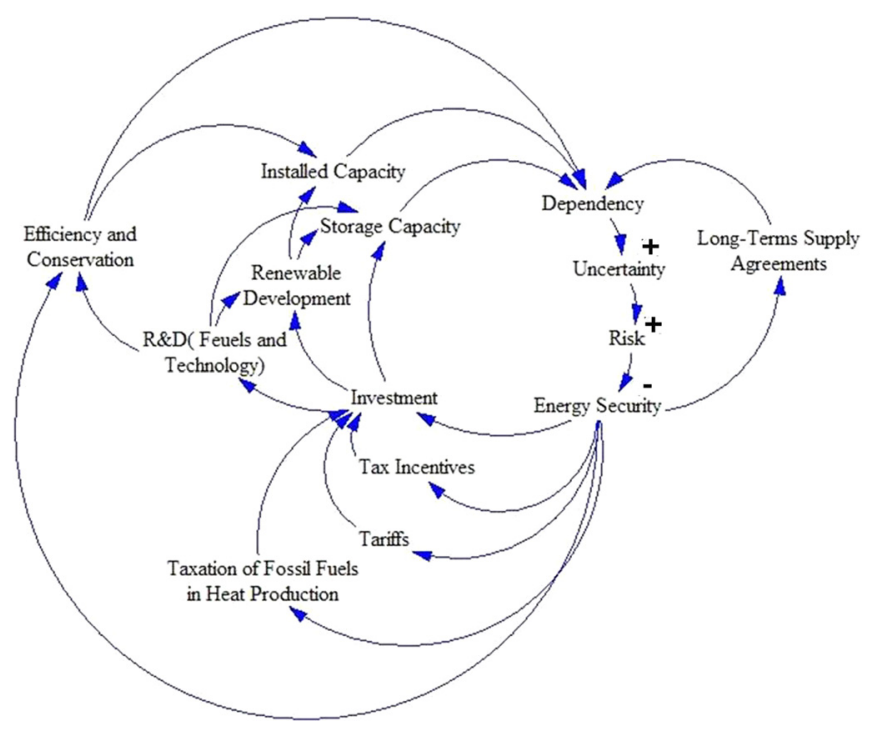

FIG. 8. Feedback structure of support schemes and policies for energy security in the Nordic countries.

the feedback structure of the Nordic support schemes can help researchers to understand, communicate, share, change, measure, simulate, and learn more about the different aspects of energy security in the Nordic countries.

In the Figure 8, the short descriptive phrases represent the support schemes and policies, and the arrows represent the causal influences between these schemes and policies with energy security. Examining the right hand side of the diagram, if the "dependency" is decreased, the "uncertainty" and thus "risk" decrease. So, the risk reduction will increase the "energy security." The simplest loop to increase the energy security in the Figure 8 is related to the "long-term supply agreements." These agreements prevent the fluctuations of energy supply, price, and dependency especially in the crisis conditions.

More than 15 loops are identified to describe the relevance of each influencing strategy and policy. For example, the "investments" affect the "storage capacity," "RE development," and "R\&D" schemes of the Nordic countries. Causal links from both "storage capacity" and "installed capacity" to "dependency" are negative. This means that the development of RE utilization decreases the dependence on imported energy.

The investments on RE development take place in the two scopes: "storage capacity" for utilized energy from RER, and diffusion of RE utilization ("installed capacity"). Generally, the investments (public or private) provide the following development loops:

(1) Development of storage capacity for different fuels and their products (e.g., strategic reserves).

(2) Diffusion of utilization from renewable alternatives (new capacities).

(3) Development of storage capacity for renewable alternatives.

(4) R\&D supports for improving the renewable technologies and storage capacity.

(5) $R \& D$ supports to improve the efficiency and conservation of current systems and new capacities.

On the other hand, "tax incentives," "tariffs," and "taxation of fossil fuels" also affect the investment too. Our studies show that the most important schemes to the diffusion of RE in the Nordic countries are subsidies and tax incentives. Taxation aims to curb the growth of energy consumption ("efficiency and conservation") and steer the production and use of energy towards alternatives with less emissions.

\section{CONCLUSION}

This article discussed how diversification strategies and policies of RE development are effective to achieve a high level of energy security in the Nordic countries. Our studies show 
that the diversification and the diffusion of RE have created incentives for various actors to make new investments and business especially in rural areas of the Nordic countries. Generally, each Nordic country has a special attention and focus on one or two RER in its policies and decision making. While Finland has chosen a policy for diffusion of biomass, Iceland has focused on the geothermal resources. Norway also has special attention to its geographical situation and utilization of electricity from hydro power. On the other hand, Denmark has selected the promotion of wind power as the main element of its new energy security policy. Finally, Sweden focuses on biomass and pellets implementation, biofuels for transport, and developing the heat pump market. This caused one-third of all heat pumps installed in Europe to be located in Sweden at this date.

On the other hand, to have the economic utilization of any energy alternative, further than sufficient resources and technology that should be available; producers should be able to have the capital and access to utilize the resources. In contrast, the consumers should also be able to afford the end product. Therefore, achieving the desired level of diversification faces challenges. ${ }^{27,28}$ Our research shows that despite all the success, the strategies of the Nordic countries for energy security and diversification development might be challenging in some cases. For example, energy security and diversification can cost more in the long-run if, for example, the market prices falls or fields turn out to be less productive or more costly. Simultaneously, building and maintaining of strategic reserves can be expensive in terms of the capital cost of building, maintaining storage facilities, the cost of transferring, and the cost of fuels purchased to fill them. As an example of the challenges of RE utilization, large scale hydro power can be controversial due to their negative impact on communities and ecologies that will be disturbed by the formation of large reservoirs. ${ }^{22}$ Therefore, these issues and other dimensions of diversification especially acceptability and affordability should be considered in the energy security studies and related future research.

In conclusion, this research helps to promote a constructive dialogue for future research among researchers, politicians, authorities and actors of the energy market especially from EU countries (e.g., Baltic region, Eastern Europe), countries out of EU but in the same natural or economic situations (e.g., Chile or Peru), and even the Nordic countries in order to comparative analysis of their weaknesses and strengths in the policies and decisions.

${ }^{1}$ U.S. Agency of International Development (USAID), Energy Security Quarterly (University of Texas, Texas, USA, 2008).

${ }^{2}$ United States Census Bureau, U.S. \& World Population Clocks (U.S. Department of Commerce, Washington, D.C., 2012).

${ }^{3}$ VÄESTÖREKISTERIKESKUS, Population Register Center for Finland (Population Register Center, Helsinki, 2012).

${ }^{4}$ SCB, Key Figures of Sweden (Swedish Administrative Agency, Stockholm, 2012).

${ }^{5}$ SSB, Key Figures of Norway (Statistics Norway's Library and Information Centre, Oslo, 2012).

${ }^{6}$ Energistyrelsen, Key Figures of Denmark (Center of Statistics Denmark, Copenhagen, 2012).

${ }^{7}$ Hagstofa Íslands, Key Figures of Iceland (Center of Statistics Iceland, Reykjavík, 2012).

${ }^{8}$ UNSD, Land Areas Part (United Nations Statistics Division, New York, 2012).

${ }^{9} \mathrm{IMF}$, Country Information: Statistics 2011 (International Monetary Fund, Washington, D.C., 2011).

${ }^{10} \mathrm{IMF}$, Country Statistics and Balances for 2009 (International Energy Agency (IEA), Paris, 2012).

${ }^{11}$ ens, Energy Statistics 2009 (Danish Energy Agency, Copenhagen, 2012).

${ }^{12}$ EIA, Energy Analysis: Country Brief (US Energy Information Administration (EIA), Washington, D.C., 2011).

${ }^{13}$ IAE, Energy Indicators for Sustainable Development: Guidelines and Methodologies (International Atomic Energy Agency, Vienna, 2005)

${ }^{14}$ I. Galarraga, M. Gonzalez-Eguino, and A. Markandya, Handbook of Sustainable Energy (Edward Elgar, UK, 2011).

${ }^{15}$ IEA, Toward a Sustainable Energy Future (The International Energy Agency (IEA), Paris, 2001).

${ }^{16} \mathrm{~J}$. M. Kendell, Measures of Oil Import Dependence (US Energy Information Administration (EIA), Washington, D.C., 1998).

${ }^{17}$ V. Costantinia, F. Graccevaa, A. Markandyaa, and G. Vicini, J. Energy Policy 35, 210 (2007).

${ }^{18}$ H. Turtona and L. Barreto, J. Energy Policy 34, 2232 (2006).

${ }^{19}$ P. Dybvig and S. A. Ross, "State prices and portfolio theory," Handbook of the Economics of Finance (Elsevier, USA, 2004), Chap. 10.

${ }^{20}$ IEA, Energy Securities and Climate Policy: Assessing Interactions, Information Paper (International Energy Agency, Paris, 2004).

${ }^{21}$ Motiva, Renewable Energy in Finland (Motiva Oy, Helsinki, 2009).

${ }^{22}$ U.S. Agency of International Development, Energy Security Quarterly: A Research Report (Center for Energy Economics Bureau of Economic Geology, The University of Texas, 2008). 
${ }^{23}$ J. C. Jansen, W. G. Van Arkel, and M. G. Boot, Designing Indicators of Long-Term Energy Supply Security. A Quest for Energy Security in the 21st Century: Resources and Constraints (Asia Pacific Energy Research Center (APERC), Tokyo, 2007).

${ }^{24}$ Orkustofnun, Geothermal Development and Research in Iceland (A report prepared by Orkustofnun, Reykjavik, 2010).

${ }^{25}$ M. M. Zuluaga and I. Dyner, J. Cleaner Prod. 15, 153 (2007).

${ }^{26}$ T. V. Mai, in System Dynamic Society's Annual International Conference: Proceedings of 2010 Conference (System Dynamics Society, New York, 2010), pp. 1-14.

${ }^{27}$ A. Aslani, M. Naaranojaa, and B. Zakerib, Renewable Sustainable Energy Rev. 16, 1977 (2012).

${ }^{28}$ A. Aslani, M. Naaranoja, E. Antila, and M. Golbaba, Int. J. Renewable Energy Res. 2, 332 (2012). Available at http:// www.ijrer.org/index.php/ijrer/article/view/201.

${ }^{29} \mathrm{~J}$. Tolonen, B. Ryden, and H. Skoldberg, Support Schemes For Renewable Energy In The Nordic Countries (Nordic Energy Perspectives Organization, Sweden, 2010). 